\title{
MECHANICAL CHARACTERISTIC STUDY OF COBALT ALLOY PREPARED BY POWDER METALLURGY METHOD
}

\author{
Aminatun ${ }^{1, a)}$, Jan $\mathrm{Ady}^{1}$, Mega Farynda $\mathrm{KD}^{1}$ \\ ${ }^{1}$ Department of Physics, Faculty of Science and Technology, Universitas Airlangga Surabaya, East Java, Indonesia \\ a) Corresponding author: aminatun@ @st.unair.ac.id
}

\begin{abstract}
This study was conducted to determine the effect of compaction pressure and sintering temperature variations on the properties of physical, mechanical, and micro cobalt alloy. Manufacture of the cobalt alloy with compositions $63,75 \%$, chromium $30 \%$, molybdenum $5 \%$, manganese $0,5 \%$, silicon $0,5 \%$, and $0,25 \%$ nitrogen using powder metallurgy method. Variations of compaction pressure were $339,70 \mathrm{MPa}, 396,31 \mathrm{MPa}$, dan $452,93 \mathrm{MPa}$, and sintered at temperature $1200^{\circ} \mathrm{C}$ and $130{ }^{\circ} \mathrm{C}$ for 2 hours of holding time. Density was increased along with the increasing compaction pressure and sintering temperature $(3,9-6,6 \mathrm{~g} / \mathrm{cm})$. The hardness was also increased along with the increasing compaction pressure and sintering temperature 205,1-316,2 VHN. XRD results showed that $\gamma$ phase with fcc structure was formed at the temperature of $1200^{\circ} \mathrm{C}$ and $1300^{\circ} \mathrm{C}$ for all variations of pressure. SEM-EDX results showed that the oxygen content decreased along with increasing compaction pressure and sintering temperature. Based on ASTM F75 hardness standard, the sample with compaction pressure $452,93 \mathrm{MPa}$ and sintered at $1300^{\circ} \mathrm{C}$ was the best cobalt alloy with a hardness value of $316.2 \mathrm{VHN}$.
\end{abstract}

\section{INTRODUCTION}

The biomaterial is used to replace or repair damaged tissue and organ. The application of biomaterial in tissue engineering includes the bone-implant, hinge joints, and artificial valves in the heart. Biomaterial needs to be biocompatible or compatible with the human body, and biofunctional or has the same function with the replaced organ. Most common materials used as biomaterial are stainless steel (SS316L), Co-Cr alloy, pure Ti (cpTi), dan Ti alloy (Ti6Al-4V) (Shamsul,A.Z. et al. 2007. Cobalt alloy had good biocompatibility, mechanic characteristic, wear resistance, and corrosion. Cobalt alloy could be obtained by powder metallurgy method which performed by sintering the compacted metal powders. This technique allowed us to adjust the pore size and distribution (Aminatun et al. 2011, Aminatun et al. 2010, Aminatun et al. 2014). Chromium was added to improve the hardness and decrease the corrosion rate, while Molybdenum also reduced the corrosion rate by preserving the passive layer of Chromium (Wiranata, Hezti. 2012). Cobalt alloy was allotropic (has different crystal form depends on temperature). At the room temperature, the crystal structure of cobalt alloy formed as hexagonal close-packed $(\varepsilon)$, while at $1300^{\circ} \mathrm{C}$, it started to form as a face centered cubic $(\gamma)$. This situation happened because of the addition of Molybdenum which had the highest melting point, so the transformation of $\varepsilon$ phase to $\gamma$ phase occurred on the higher temperature (Yuswono, Pramono, Andika, 2010)

The previous making of cobalt alloy by powder metallurgy method was done by using the variation of $\mathrm{Si}$ (Silicon) ingredient and sintering temperature (Yuswono, Pramono, Andika, 2010, Rodrigues, W.C., et al., 2010, Ghazali, M. Kamardan, 2010 ). Based on the previous experiment, this study will discuss the effect of compaction pressure and sintering temperature on the mechanical characteristic of the cobalt alloy. The compaction process helped the bonding process of particles while sintering. 


\section{EXPERIMENTAL METHOD}

\section{Material}

The material used to make samples were Cobalt powder (Co), Chromium powder (Cr), Molybdenum powder (Mo), Mangan powder (Mn), Silicon powder (Si), and $\mathrm{Cr}_{2} \mathrm{~N}$ powder from sigma Aldrich.

\section{Equipment}

This study used the spatula, aluminium foil, crucible alumina, digital scales, hydraulic machine, High Energy Milling HEM-E3D, furnace programable, dies and punch to make samples. There were three main tools for sample characterization purpose, including Scanning Electron Microscopy (SEM) FEI type inspect S50, X-ray diffractometer PANalytical X'Pert PRO for XRD test, and Microvickers Hardness Test.

\section{Sample Processing}

\section{Material Mixing}

The first step was weighing materials based on Table 1; the mass percent referred on ASTM F75. The weighed materials were mixed using High Energy Milling for 15 minutes at $350 \mathrm{rpm}$.

\section{Compaction Process}

The mixed materials were then compacted using dies and punch at $200^{\circ} \mathrm{C}$ or hot pressing temperature. The variations of compaction were 339,70 MPa (for 6 ton of load), 396,31 MPa (for 7 ton of load) dan 452,93 MPa (for 8 ton of load). Each variation was withheld for 10 minutes.

TABLE 1. The Composition of Cobalt Alloy

\begin{tabular}{lcc}
\hline \multicolumn{1}{c}{ Element } & Percentage of Mass Percent (\%) & Mass (gram) \\
\hline Chomium $(\mathrm{Cr})$ & $30 \%$ & 0,6 \\
\hline Molibdenum $(\mathrm{Mo})$ & $5 \%$ & 0,1 \\
\hline Mangan $(\mathrm{Mn})$ & $0,5 \%$ & 0,01 \\
\hline Silicon $(\mathrm{Si})$ & $0,5 \%$ & 0,01 \\
\hline Nitrogen $(\mathrm{N})$ & $0,25 \%$ & 0,005 \\
\hline Cobalt $(\mathrm{Co})$ & $63,75 \%$ & 1,275 \\
\hline Total & $100 \%$ & 2 \\
\hline
\end{tabular}

\section{Sintering Process}

Each compacted samples were then sintered at $1200^{\circ} \mathrm{C}$ and $1300^{\circ} \mathrm{C}$ using Furnace Programmable and withheld for two hours. The furnace was supplied with Argon on the heating process to avoid oxidation.

\section{Grinding Process}

Before characterized, the samples were sanded, from the rough until the smooth one using sandpaper with the size of $200-1200$ mesh. This process involved fluid-flowing using the clean water to avoid the heating on samples surface that directly contacted by sandpaper and remove abrasive materials on samples surface. 


\section{Sample Characterization}

XRD test was conducted to identify the formed crystal phase, while the SEM-EDX test was done to determine the morphology of samples surface along with the composition. The hardness test was carried out using Microvickers Hardness Test, and the samples were also measured to obtain its density.

\section{RESULTS AND DISCUSSIONS}

The samples of cobalt alloy after compacted, sintered, and grinded showed in Figure 1.

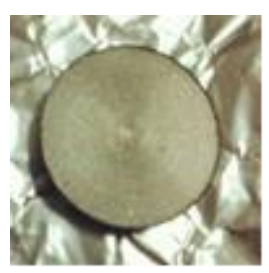

(a)

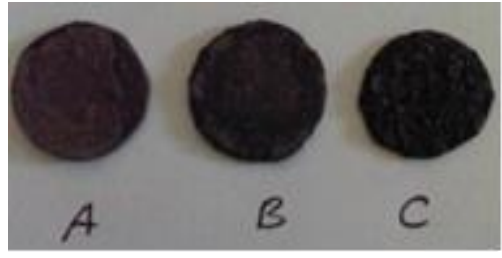

(b)

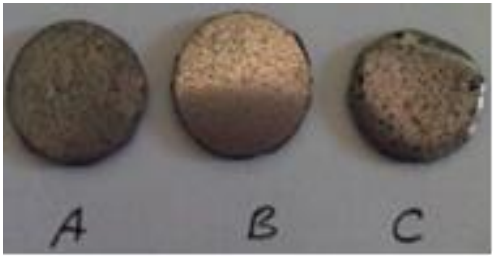

(c)

FIGURE 1. (a) Compacted sample; (b) Sintered samples; (c) Grinded samples

After the powder materials compacted, it formed a solid form with a diameter of $15 \mathrm{~mm}$ and a width of $2 \mathrm{~mm}$, as showed in Figure 1 (a). Figure 1(b) showed that the surface of the samples after the sintering process was black, which indicated the oxide layer after heated in high temperature. The oxide layer should be removed to ease the characterization process by grinding. The result after the grinding process was shown in Figure 1(c).

\section{Cobalt Alloy Crystal Structure}

The formed phase structure of cobalt alloy was identified using XRD test by comparing the peak of the diffraction manually (Aminatun et al. 2014). The peak information could be identified as $\gamma, \varepsilon$, or $\sigma$ phase if the difference between XRD result and the literature below FWHM. The diffraction pattern of XRD results and the phase identification of samples were shown in Figure 2 to Figure 7.

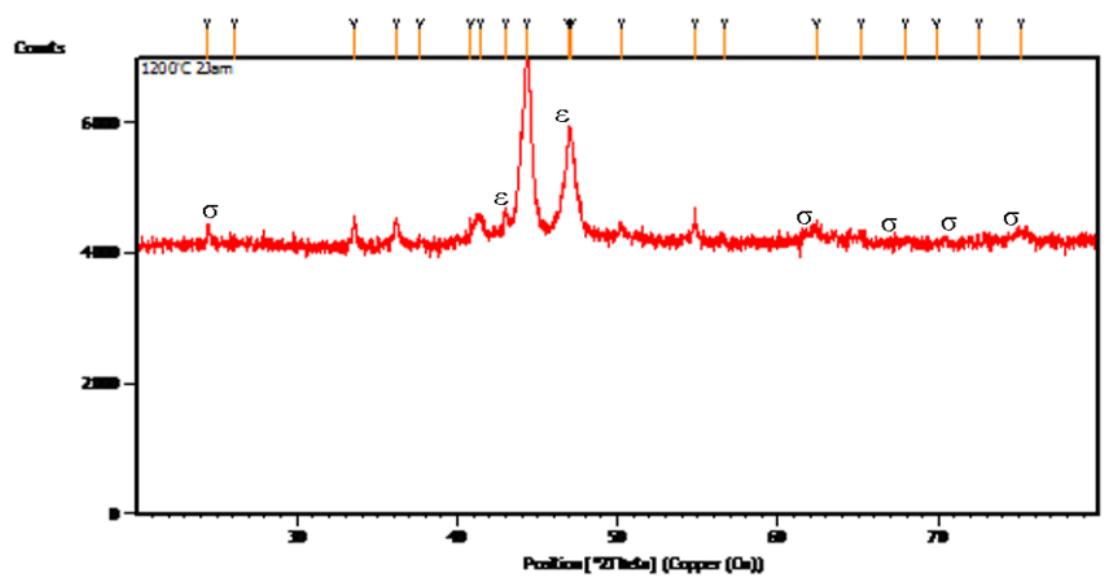

FIGURE 2. Peak sample identification of $339,70 \mathrm{MPa}, 1200^{\circ} \mathrm{C}$ (A1) 


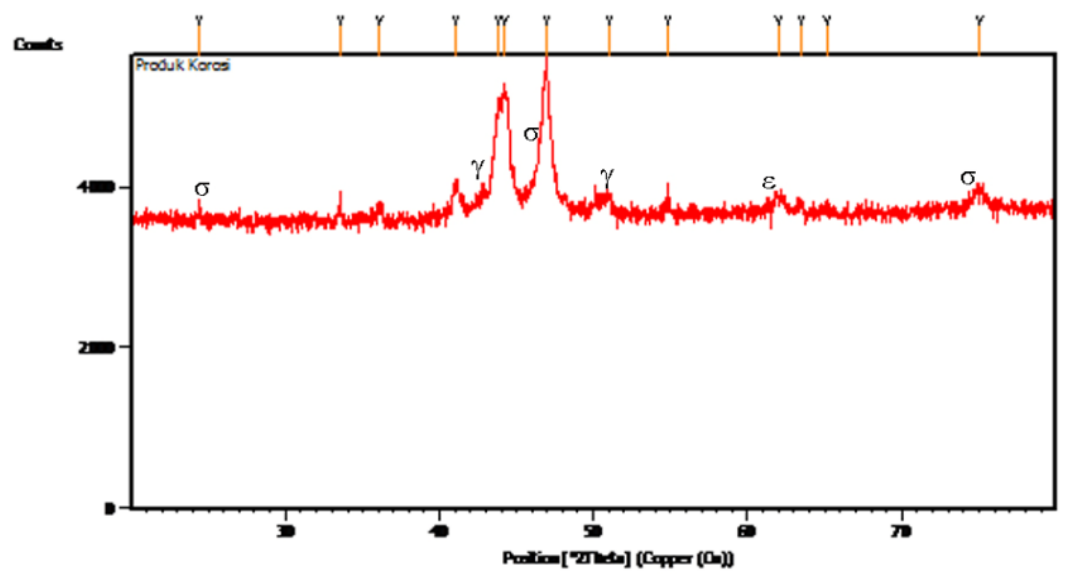

FIGURE 3. Peak sample identification $339,70 \mathrm{MPa}, 1300^{\circ} \mathrm{C}$ (A2)

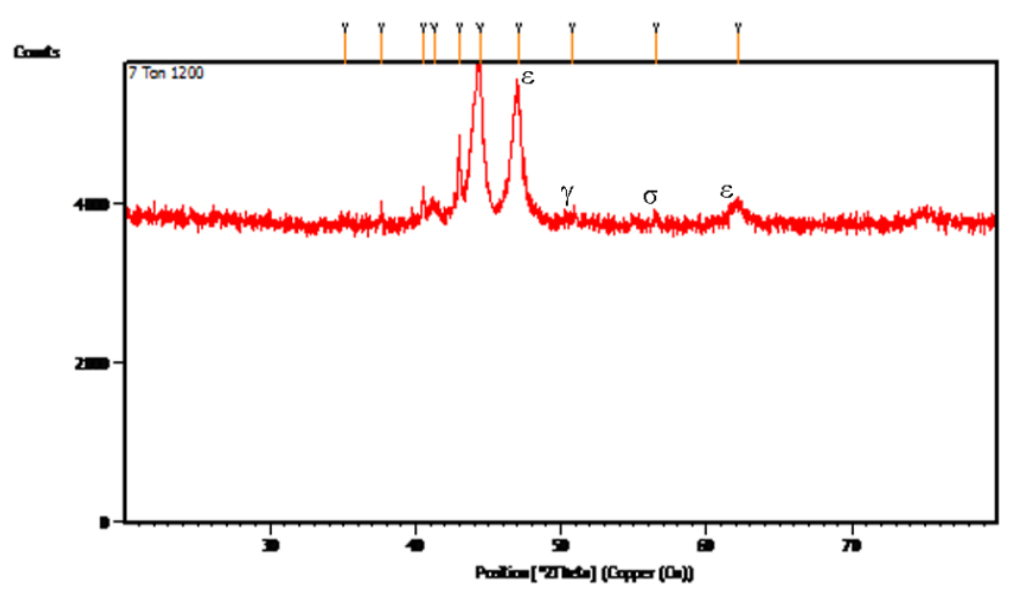

FIGURE 4. Peak sample identification $396,31 \mathrm{MPa}, 1200^{\circ} \mathrm{C}$ (B1)

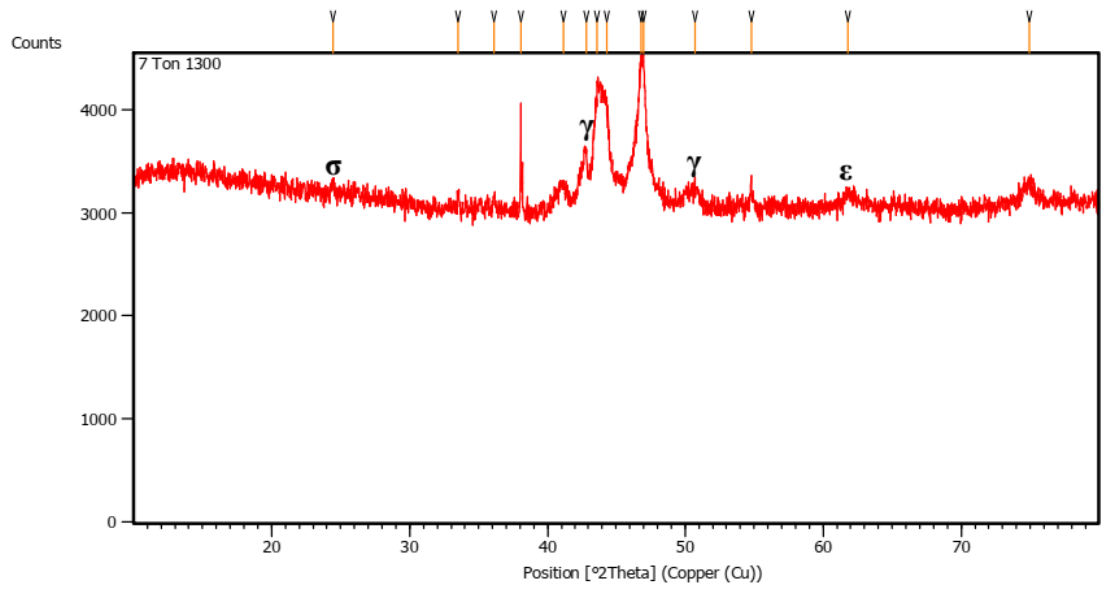

FIGURE 5. Peak sample identification $396,31 \mathrm{MPa}, 1300^{\circ} \mathrm{C}$ (B2) 


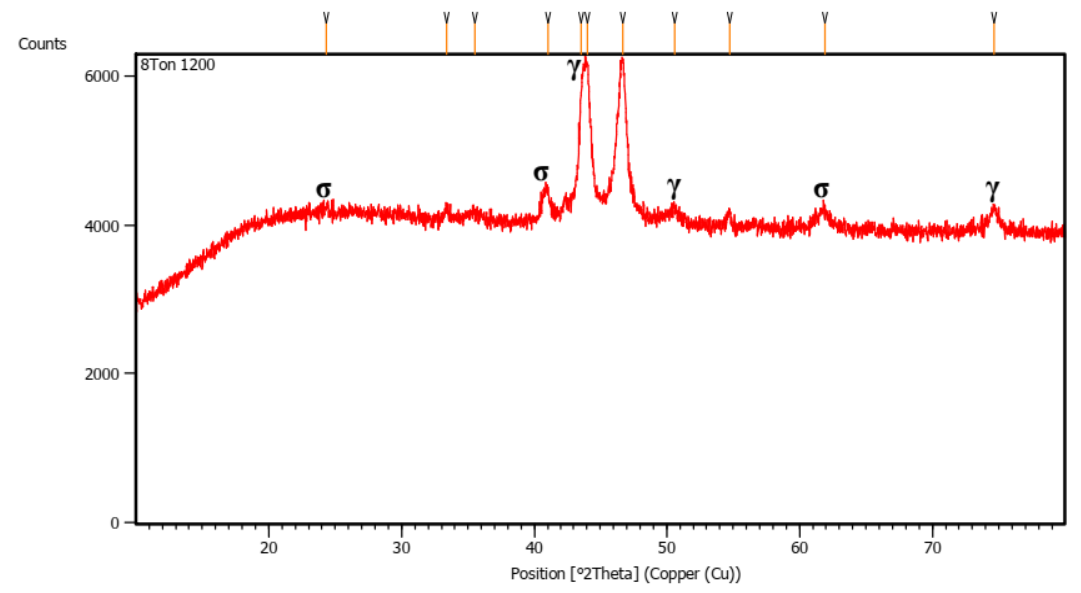

FIGURE 6. Peak sample identification $452,93 \mathrm{MPa}, 1200^{\circ} \mathrm{C}(\mathrm{C} 1)$

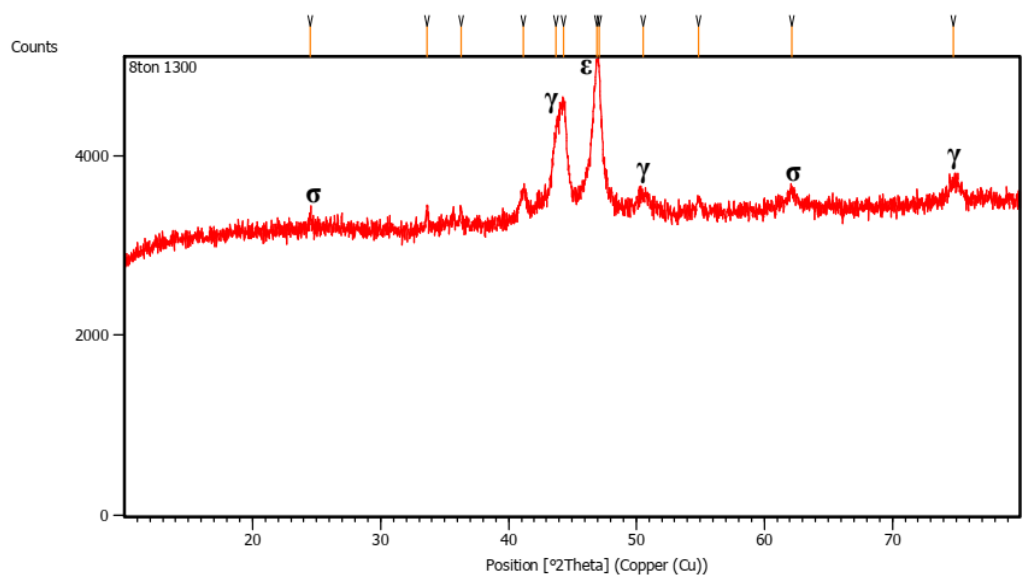

FIGURE 7. Peak sample identification $452,93 \mathrm{MPa}, 1300^{\circ} \mathrm{C}(\mathrm{C} 2)$

Based on the diffraction pattern graphs, the fcc crystal structure of $\gamma$ phase had formed, except for the $\mathrm{A}_{1}$ sample. The samples of $\mathrm{B}_{1}$ dan $\mathrm{C}_{1}$ had a different compaction pressure and sintering temperature of $1200^{\circ} \mathrm{C}$. Other samples that sintered at $1300^{\circ} \mathrm{C}$ also shown the $\gamma$ phase. These phenomena showed that the compaction pressure affected the phase formation of the cobalt alloy, which is the transformation from $\varepsilon$ phase to the $\gamma$ phase. Figure 4 and Figure 5 showed that the $\gamma$ phase formed at the higher temperature of $1300^{\circ} \mathrm{C}$ with constant compaction pressure. These results were correlated to the ternary diagram, which stated that the $\gamma$ phase of $396,31 \mathrm{MPa}, 1300^{\circ} \mathrm{C}\left(\mathrm{B}_{2}\right)$ formed at $1300^{\circ} \mathrm{C}$. 
Surface morphology and the element composition of cobalt alloy

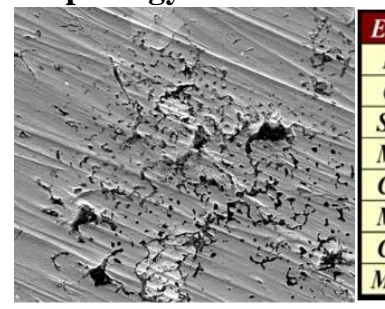

\begin{tabular}{|l|l|l|}
\hline Element & $\boldsymbol{W t} \%$ & $\boldsymbol{A t} \%$ \\
\hline $\boldsymbol{N K}$ & 03.43 & 08.47 \\
\hline $\boldsymbol{O K}$ & 20.86 & 45.12 \\
\hline SiK & 05.30 & 06.53 \\
\hline MoL & 12.32 & 04.44 \\
\hline $\boldsymbol{C r} \boldsymbol{K}$ & 15.74 & 10.48 \\
\hline MnK & 01.54 & 00.97 \\
\hline CoK & 40.81 & 23.97 \\
\hline Matrix & Correction & ZAF \\
\hline
\end{tabular}
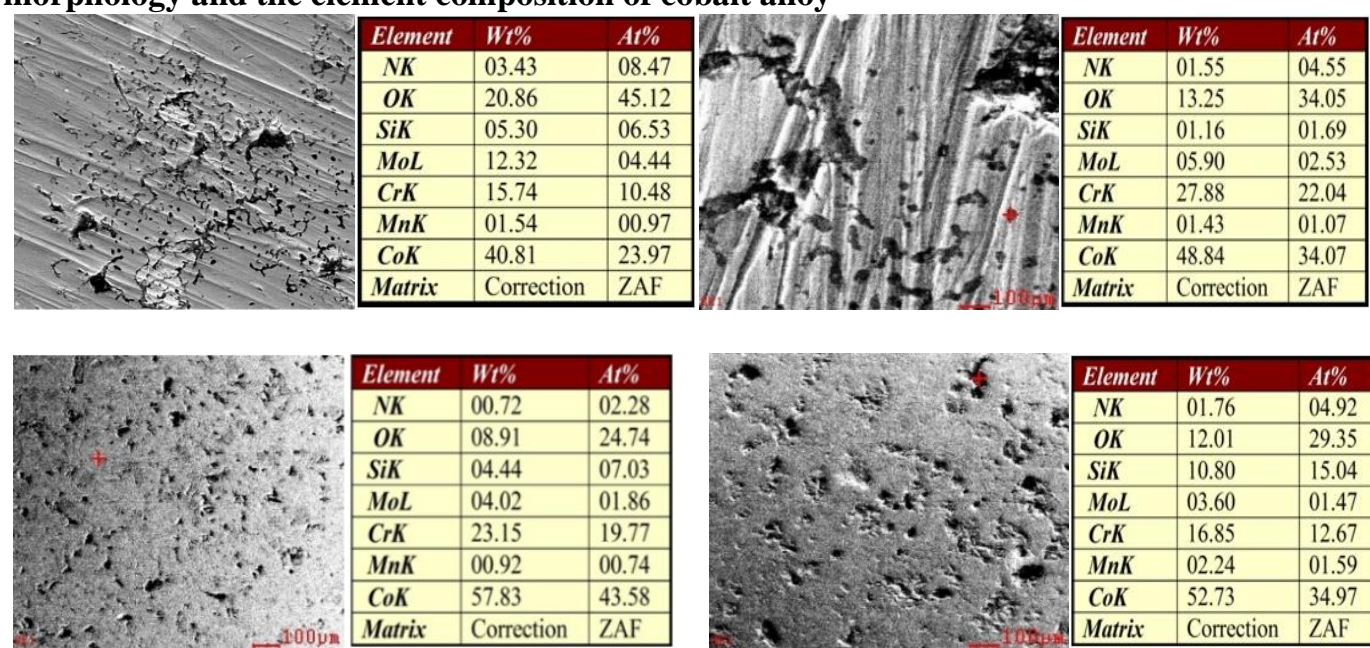

\begin{tabular}{|l|l|l|}
\hline Element & $\boldsymbol{W t} \%$ & At $\%$ \\
\hline NK & 00.72 & 02.28 \\
\hline OK & 08.91 & 24.74 \\
\hline SiK & 04.44 & 07.03 \\
\hline MoL & 04.02 & 01.86 \\
\hline CrK & 23.15 & 19.77 \\
\hline MnK & 00.92 & 00.74 \\
\hline CoK & 57.83 & 43.58 \\
\hline Matrix & Correction & ZAF \\
\hline
\end{tabular}
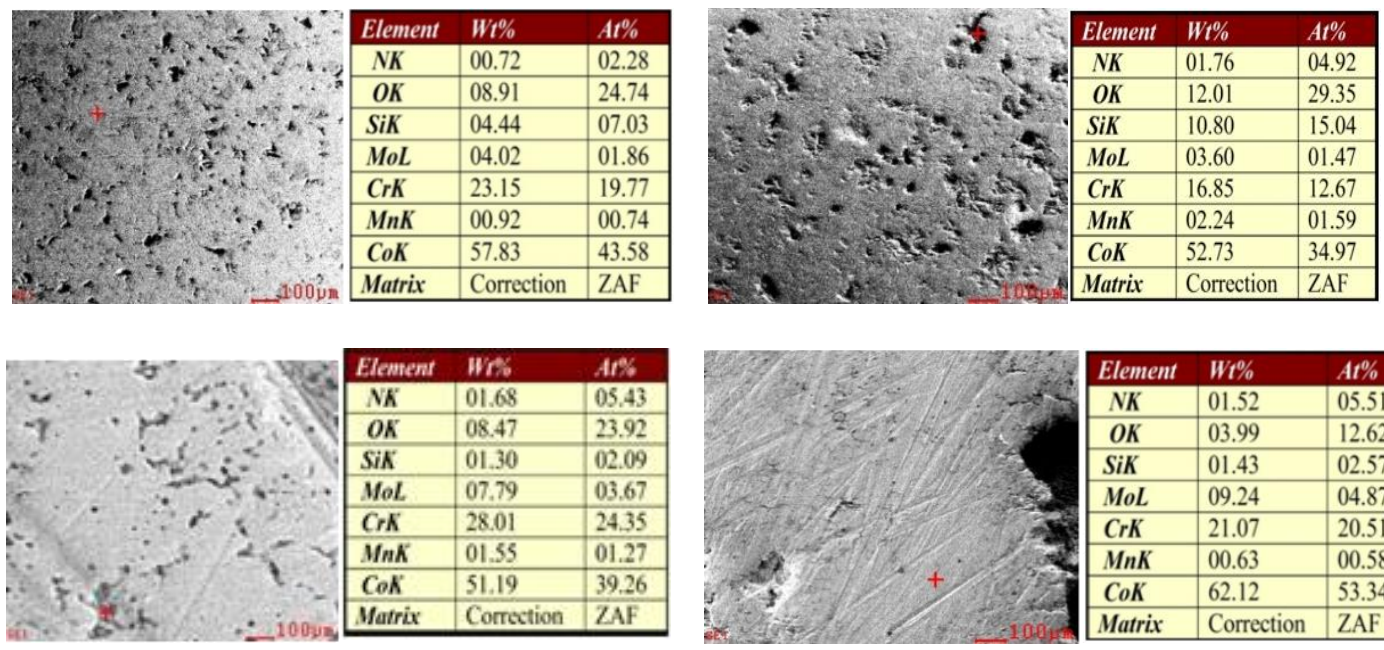

\begin{tabular}{|l|l|l|}
\hline Element & Wt\% & At $\%$ \\
\hline NK & 01.52 & 05.51 \\
\hline OK & 03.99 & 12.62 \\
\hline SiK & 01.43 & 02.57 \\
\hline MoL & 09.24 & 04.87 \\
\hline CrK & 21.07 & 20.51 \\
\hline MnK & 00.63 & 00.58 \\
\hline CoK & 62.12 & 53.34 \\
\hline Matrix & Correction & ZAF \\
\hline
\end{tabular}

FIGURE 8. (a) A1 sample; (b) A2 sample; (c) $\mathrm{B}_{1}$ sample; (d) $\mathrm{B}_{2}$ sample; (e) $\mathrm{C}_{1}$ sample; (f) $\mathrm{C}_{2}$ sample.

The SEM-EDX test was carried out to determine the surface morphology and the element distribution of cobalt alloy. Figure 8 (a) to Figure 8 (f) showed the percentage of oxygen content variation, which caused the oxidation. The furnace that supplied by Argon allowed the air trapped inside the furnace and also led the oxidation.

Figure 8 showed that the oxygen content was decreased along with the increased compaction pressure, which led to the reduction of free space, so the air trapped decreased. The compaction pressure also allowed the bonding between particles and interaction between surfaces to generate the denser powder and reduce the porosity. The pores distribution was also decreased along with the increased compaction pressure, as shown in Figure 8 (a), (c), (e).

The increased of sintering temperature also decreased the pore distribution since the heating process increased the energy of the particles and generated the mass transport along with the formation of the neck region which led to matrix interface bonding and reinforcement. While the compaction pressure was increased, the shrinkage process in sintering process decreased along with its porosity, causing the increased in density.

\section{Density}

The density was the ratio of mass and volume of the sample after sintering and grinding process. Figure 9 showed the density of the samples in different sintering temperature. 


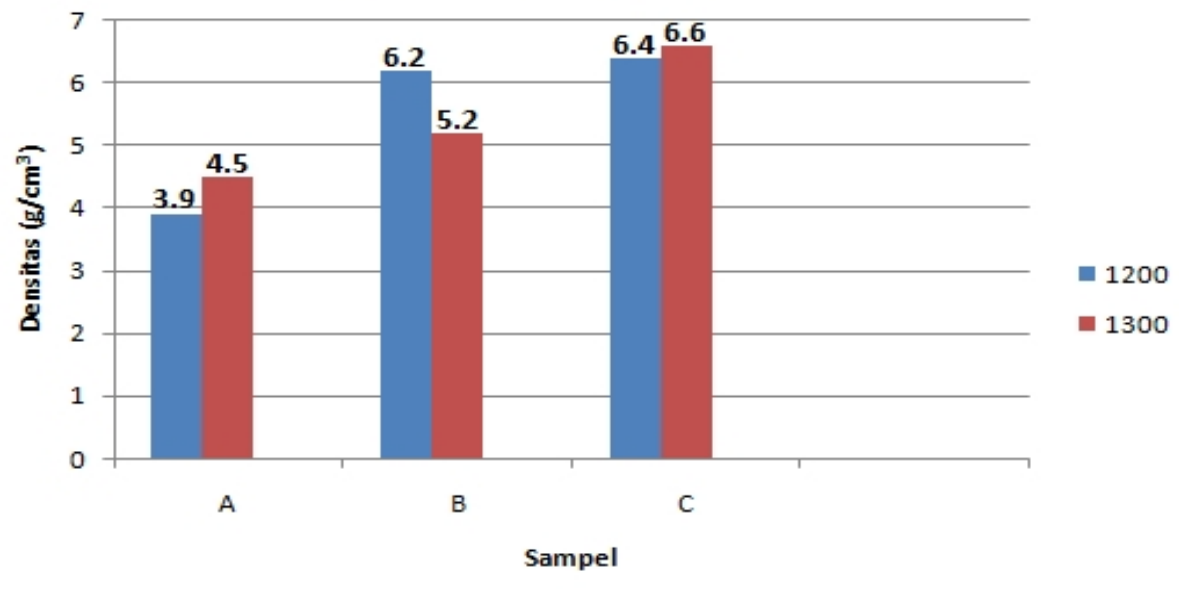

FIGURE 9. The density of A, B dan $\mathrm{C}$ at $1200{ }^{\circ} \mathrm{C}$ and $1300^{\circ} \mathrm{C}$

The increased of compaction process and sintering temperature affected the increment of the density of samples. Powdered particles were arranged and formed in the compaction process and caused the plastic and elastic deformation, powder demolition and compression, and density increment.

The density was formed by the particles interface bonding due to the surface roughness. The mechanism of the bonding was cold-weld bonding between the interface of two metal surfaces which occurred by powder cohesion without melting and heating effect (Lestari, Franciska Pramuji. 2008). The density was increased after sintering process since the particles were bonding with each other and formed the neck region.

Sintering temperature was one of the diffusion motive force parameters; the atoms moved from the higher to the lower concentration. The higher density generated the denser samples since its particles strongly bonding to each other.

According to WHO, the compatible density for the normal human body (without osteopenia and osteoporosis) was $3.0 \mathrm{~g} . \mathrm{cm}^{-3}-9.4 \mathrm{~g} . \mathrm{cm}^{-3}$ (Aminatun et al. 2010). Therefore, the samples of $\mathrm{B}_{1}$ to $\mathrm{C}_{2}$ were potential as a bone implant.

\section{Vickers Hardness of Cobalt Alloy}

Micro Vickers hardness was used to determine the hardness of the samples using three different points to obtain the average hardness with the applied force of 1000 (gf). Figure 10 showed that the higher compaction pressure and sintering temperature, then the hardness was also higher. The increased compaction pressure at constant sintering temperature also increased the density of $\mathrm{A}_{1}, \mathrm{~B}_{1}$, dan $\mathrm{C}_{1}$ samples, as shown in Figure 9. This condition affected the hardness value, which represented in Figure 10. 


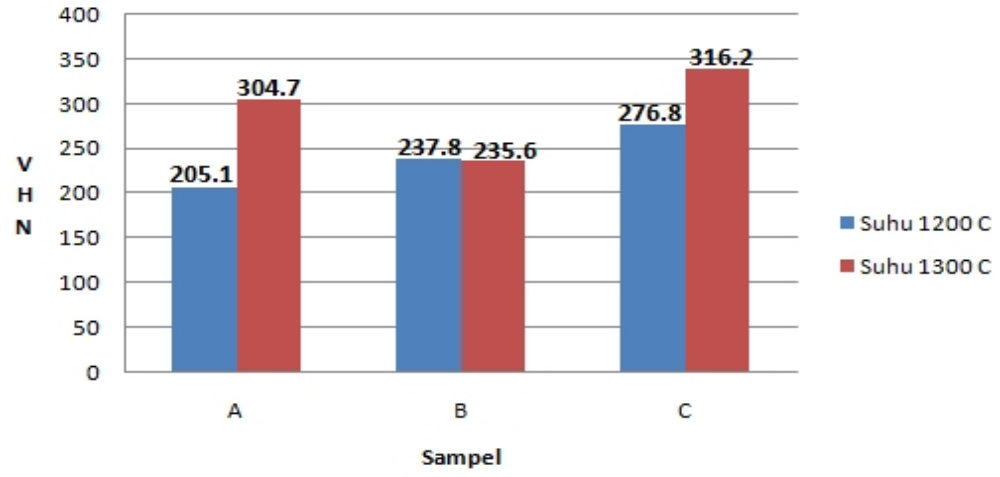

FIGURE 10.. Micro Vickers Hardness Test Results of the samples

Figure 9 represented that the different sintering temperature with the constant compaction pressure increased the density of the samples, which also affected the higher hardness value, as shown in Figure 10. The formed green body was denser along with the higher compaction pressure, so the density was also increased (Seprianto, Dicky., 2010, Rusianto, Toto, 2009). The strong bonding between particles caused the higher of the hardness value, which occurred along with the increased sintering temperature (Amin, Muh. Analisis , 2009). However, the hardness value of $\mathrm{B}_{2}$ decreased along with its density. This case could happen because of the imperfect compaction process, causing the hollow spaces which unfilled by metal powder, so the sample was shrunk more extensive on the sintering process.

The $\mathrm{C}_{2}$ sample with compaction pressure of $452,93 \mathrm{MPa}$ at $1300^{\circ} \mathrm{C}$ sintering temperature had the highest hardness value of 316,2 VHN along with the higher density. Based on the ASTM F75 standard, the compatible hardness value was $25-35 \mathrm{HRC}$ or $265<\mathrm{VHN}<350$, which was on samples $\mathrm{A}_{2}, \mathrm{C}_{1}$, dan $\mathrm{C}_{2}$.

\section{CONCLUSION}

The increased of the compaction pressure from 339,70 to $452,93 \mathrm{MPa}$ and the sintering temperature of $1200^{\circ} \mathrm{C}$ and $1300^{\circ} \mathrm{C}$ caused the increased density and hardness value. The $\gamma$ phase formed at $1200^{\circ} \mathrm{C}$ an $\mathrm{d} 1300^{\circ} \mathrm{C}$ sintering temperature for all samples except $\mathrm{A}_{1}\left(339,70 \mathrm{MPa}, 1200^{\circ} \mathrm{C}\right)$. The best cobalt alloy that had potential as the boneimplant had $316,2 \mathrm{VHN}$ of hardness value with $452,93 \mathrm{MPa}$ compaction pressure at $1300^{\circ} \mathrm{C}$ sintering temperature.

\section{REFERENCE}

1. Shamsul,A.Z, Nur Hidayah, dan C.M.Ruzaldi. 2007. Fabrication and Propertis of Cobalt-Chromium HAP Composite. School of Materials Engineering. Universiti Malaysia Perlis. Internasional Jurnal Science ISSN 09734589 Volume 3, Number 1(2008),pp 35-31 OResearch India Publication.

2. Aminatun, Siswanto, Fitri W. The Effect of Co:Cr Variation to Mechanical Properties and cytotoxicity Co-CrHA Composite . Proceeding of The ${ }^{\text {rd }}$ International Conferences and Workshops on Basic and Applied Sciences 2011, 22 Sep 2011-Unair-Surabaya

3. Aminatun, Jan Ady, Tri Saktiani dan Suhariningsih, Kajian Proses Sintering Pada Metode Metalurgi Serbuk Paduan Kobalt Sebagai Kandidat Material Implan Tulang, Jurnal MIPA - Universitas Airlangga, Vol. 17, No.1, Januari 2014

4. Aminatun, Siswanto, Wheni K, Sintesis dan Karakterisasi Sifat-Sifat Fisis CIC (Cobalt-Implant Composit) karena Variasi Konsentrasi Hidroksiapatit. Prosiding Seminar Nasional Sains 2010, 16 Jan 2010, Pasca Sarjana Unesa Surabaya

5. Wiranata, Hezti. 2012. Sintesis Paduan CoCrMo dengan Variasi Kandungan Nitrogen. Skripsi Fisika Fakultas Matematika dan Ilmu Pengetahuan Institut Pertanian Bogor 
6. Yuswono, Pramono, Andika. Pembuatan Paduan Logam Co-30\%Cr-6\%Mo Melalui Pengerjaan Kompak dan Sinter dan Pengaruhnya Terhadap , Kandungan Si. 2010. Vol. 10 No.2 Desember 2010: 110-118.

7. Rodrigues, W.C., Broilo, L.B., Schaeffer, Lirio. 2010. Powder Metallurgical Processing of Co-28\%Cr-6\%Mo for Dental Implants :Physical, Mechanical and Electrochemical Properties. PTEC-08054 : Elsevier.

8. Ghazali, M. Kamardan. The Sintering Temperature Effect on the Shrinkage Behavior of Cobalt Chromium Alloy. American Journal of Applied Sciences. 2010.7 (11): 1443- 1448.

9. Aminatun, Efinda Putri N.S, Arista Indriani, Umi Himawati, Dyah Hikmawati and Suhariningsih, Synthesis of Cobalt Alloy Through Smelting Method and Its Characterization as Bone Implant Prosthesis, (AIP (American Institute of Physics) Conference Proceeding, 2014. Volume 1617: 137

10. Lestari, Franciska Pramuji. 2008. Pengaruh Temperatur Sinter dan Fraksi Volume Penguat A12O3 Terhadap Karakteristik Komposit Laminat Hibrid A1/SiC-Al/A12O3 Produk Metalurgi Serbuk. Skripsi Teknik Metalurgi dan Material Fakultas Teknik Universitas Indonesia.

11. Seprianto, Dicky. Pengaruh Kompaksi Dan Holding Time Terhadap Densitas Paduan Aluminium/Fly Ash Yang Dibuat Dengan Metalurgi Serbuk. Jurnal Austenit 2010.Volume 2 Nomor 1.

12. Rusianto, Toto. Hot Pressing Metalurgi Serbuk Aluminium Dengan Variasi Suhu Pemanasan. Jurnal Teknologi. 2009. Volume 2 Nomor 1: 89-95.

13. Amin, Muh. Analisis Harga Fracture Toughness Dengan Metode Indentasi Kekerasan Vickers Pada Keramik Kaolin. Traksi. 2009.Vol 9 No.1, Juni 2009. 